\title{
Geological and engineering conditions of deposits as foundation of their safe development
}

\author{
Irina Abaturova, Lyubov Storozhenko*, Ivan Savintsev, and Irina Petrova \\ Ural State Mining University, 620144, Kuibyshev st., 30, Ekaterinburg, Russia
}

\begin{abstract}
The article studies geological and engineering conditions of the mineral deposits located in cryolithic zone. The demand to study and analyze geological and engineering conditions is justified by safety requirements established to development of the deposits. The article is focused on pebblephosphate deposit located in Polar Urals. The geological and engineering conditions of this site fall within very severe category, which is connected with endogenetic and exogenic processes of its accumulation. It is the genesis of the deposit that generated the factors that complicate drilling-in conditions, included but not limited to weathering crusts with significant depths and discontinuity, frozen rock mass and its cavernous porosity.
\end{abstract}

The best extraction and safety of the mining operations is primarily ensured by the most mature exploration of geological and engineering conditions, enabling to predict the risks and scales of progress of dangerous engineering-geologic processes. The methodology of research and assessment of geological and engineering conditions of the rock mass takes the top priority in this regard. That would ensure effective management of capital investments during design and construction of mining plants. Results obtained at assessment of geological and engineering conditions must describe the actual conditions with the best accuracy possible, since any errors contribute to deviation of performance indicators and imperfections of design solutions against the best ones [1-10].

Let's study some approaches to obtaining engineering-geological information through the example of Sofronovskoe pebble-phosphate deposit located in Polar Urals. Conditions of accumulation of the mineral are connected with the most complicated endogenetic and exogenic processes, which left a certain footprint on some factors defining strength of the rocks at their excavation by $200 \mathrm{~m}$ deep pit.

\section{Approaches and methodology}

Complexity of environmental conditions, survey maturity and scheduled method of mineral miming determine the approaches applicable to obtaining engineering-geological information. The choice of essential methodology tools and techniques is determined by two main goals to be reached [8-9]:

\footnotetext{
*Corresponding author: stor_luba@mail.ru
} 
1) survey of geological engineering conditions based on special field, lab and in-office studies;

2) assessment of predicted parameters characterizing changes of engineeringgeological conditions and progress of man-caused processes.

Therefore, the research methodology for Sofronovskoe deposit was focused on obtaining the information about generation of perennially frozen rocks, their properties and structure, their type, weathering crust type, extent of cavernous porosity of the mass. The complex of methods used to this end is listed in the Table 1.

\section{Results}

The rock phosphates are among the hardest mineral raw materials within Paleozoic of the central area of the Polar Urals from their formation perspective. Sofronovskoe deposit is a result of manifestation of weathering of primary phosphate rocks. It is characterized by rich reserves of high-quality supergene rock phosphates, suitable for direct application as ground phosphate rock and production of compound fertilizers.

The geological profile of the deposit features Paleozoic rocks, further divided into three rock masses: terrigenous-carbonate Malopaypudynskaya series of lower-middle Ordovian system, shale productive series of the upper Ordovian, Paypudyn Whistle carbon-bearing series of lower Silurian age embedded with tectonic contact (thrust) in the massif. Primary ore formation is connected with inclusions of layers and lenses of phosphate and siliceous composition in the shaly embedded rock. Formation of the secondary rock phosphates is a result of weathering process. (Figure 1).

Table 1. Complex of methods of obtaining information on components of engineering and geological conditions of deposits of hard minerals in frozen rock masses

\begin{tabular}{|c|c|c|c|c|c|c|c|c|c|c|c|c|c|c|c|}
\hline \multirow{3}{*}{$\begin{array}{l}\text { Complex of methods } \\
\text { Physical mechanical } \\
\text { properties }\end{array}$} & \multicolumn{15}{|c|}{ Main characteristics of permafrost massifs } \\
\hline & \multirow{2}{*}{ 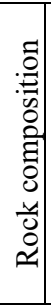 } & \multirow{2}{*}{ 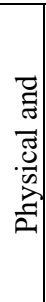 } & \multirow{2}{*}{ 告 } & \multirow{2}{*}{ 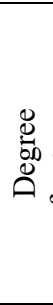 } & \multirow{2}{*}{ 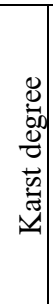 } & \multirow{2}{*}{ 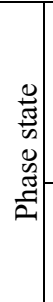 } & \multicolumn{2}{|c|}{$\begin{array}{l}\text { distrib } \\
\text { ution } \\
\text { of } \\
\text { permaf } \\
\text { rost }\end{array}$} & \multirow{2}{*}{ 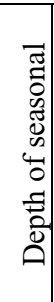 } & \multirow{2}{*}{ 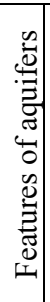 } & \multirow[t]{2}{*}{$\begin{array}{c}\mathfrak{n} \\
\frac{n}{0} \\
0 \\
0 \\
+\end{array}$} & \multirow{2}{*}{$\begin{array}{c}0 \\
\Xi \\
0 \\
0 \\
\Xi \\
0 \\
0 \\
0 \\
0 \\
0 \\
0 \\
0 \\
0 \\
0\end{array}$} & \multirow{2}{*}{ 离: } & \multirow{2}{*}{ 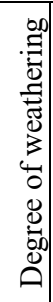 } & \multirow{2}{*}{$\begin{array}{l}\bar{\Xi} \\
.0 \\
0 \\
0 \\
0 \\
0 \\
0 \\
0 \\
0 \\
0 \\
0 \\
0 \\
x \\
x\end{array}$} \\
\hline & & & & & & &.$\Xi$ & $\stackrel{\varpi}{\Xi}$ & & & & & & & \\
\hline $\begin{array}{l}\text { Engineering-geological } \\
\text { (engineering-geocryological) } \\
\text { survey }\end{array}$ & + & + & + & + & + & + & + & - & + & - & + & + & + & + & + \\
\hline Well drilling, core drilling & + & - & + & + & + & + & - & + & + & - & - & + & + & + & + \\
\hline $\begin{array}{l}\text { Engineering-geological } \\
\text { documentation }\end{array}$ & + & + & + & + & + & + & - & + & + & - & - & + & + & + & + \\
\hline $\begin{array}{l}\text { Engineering-geological } \\
\text { approbation }\end{array}$ & + & + & - & - & - & + & - & - & - & - & - & + & + & + & - \\
\hline \multicolumn{16}{|l|}{$\begin{array}{l}\text { Field experimental filtration } \\
\text { work: }\end{array}$} \\
\hline - hydrogeological & - & - & - & + & - & - & - & - & - & - & - & - & + & - & - \\
\hline - temperature & - & - & - & - & - & + & - & + & + & - & + & - & + & - & - \\
\hline $\begin{array}{l}\text { Field analysis of physical } \\
\text { and mechanical properties }\end{array}$ & + & + & - & + & - & + & + & + & + & - & - & + & - & + & - \\
\hline Geophysical work & + & + & + & + & - & + & + & + & + & - & + & + & + & - & - \\
\hline $\begin{array}{l}\text { Thermal imaging (satellite } \\
\text { and air base surveys) }\end{array}$ & - & - & - & - & - & - & + & + & + & - & + & - & + & - & - \\
\hline
\end{tabular}




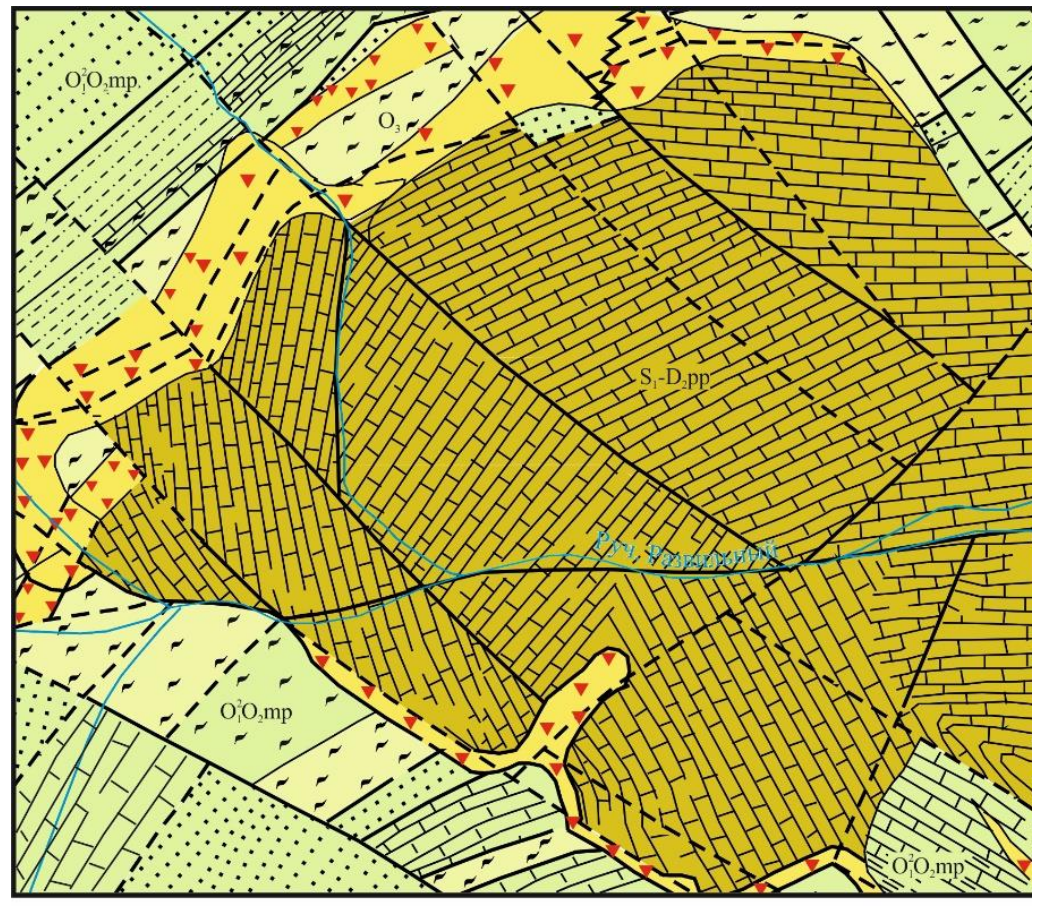

1 - Silurian

System, Middle

Division of

Devonian

Whistle,

Paypudyn

Whistle, Marble

Limestone;

2-Ordovian

system, upper

department,

Productive

whistle,

phosphorites,

shale sericite-

quartz, limestone;

3 - Ordovian

system, lower-

middle section,

Malopaypudynsk

aya suite,

carbonate-quartz

carbonaceous

phosphorite

schists

containing,

sandstone

limestone's,

calcareous

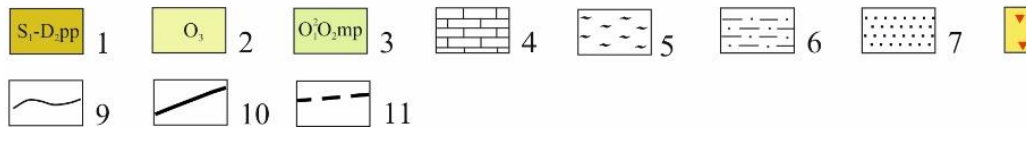

sandstones.

Lithologic

structure:

4-limestones,

5 - shale sericite-

quartz;

6 - silty

sandstone;

7 - sandstones; 8

- phosphorites;

9 - stratigraphic

boundaries;

10 - broken

violations;

11 - break

violations

alleged.

Fig. 1. Fragment of the geological map of the Sofronovskoe deposit

Special part in formation of the deposit is taken by three interlinked types of disjunctive dislocations as ore control structures which are further categorized in relation to strike of the Paleozoic rocks into longitudinal (North-Eastern), transverse (North-Western) and break cover type crush movements (Figure 1). The systems of faults (sublatitudinal and submeridional profile) is underdeveloped and adds up to three previous ones. The combination of fault systems resulted in formation of synclinal (graben type) and anticlinal (the Gorstian type) quartic structures: 'Razvilnenskaya' graben-syncline, 'Dyavolskaya' Gorstian anticline. The Malopaypudynsy longitudinal fault is indicated in central part of the deposit. It is represented by series of contiguous highangled upcasts of the south-eastern drop with shift up to $300 \mathrm{~m}$. The number and intensity of such faults decreases to the North-west 
and South-west of the fault. The cross-dislocation system represents a series of near-vertical faults of shift-faulting type, clustering in deep tectonic zone of North-western extension (Razvilnensky fault). Plicative dislocations have subordinate value and are expressed by near-fault orogenesis, and plicature.

One of the key points for assessment of engineering-geological conditions of the mineral deposits is identification and determination of components that establish conditions for deposit opening. The following qualify as such components for the Sofronovskoe deposit: presence of strong weathering crust, nonuniform distribution of perennially frozen rocks and cavernous porosity of the rocks.

Distribution of weathering crusts. The deposit is specific due to presence of the weathering crust, which features negative temperatures, and is characterized by complex morphology and specifics related to structure and mode of occurrence (Figure 2). Based on morphology and genesis, linear and linear-karstic types of crusts, exposed at depth up to 140$160 \mathrm{~m}$, are distinguished. Geologically complicated establishment of the rock massif connected with stages of manifestation of endogenetic and exogenic processes formed the following weathering zones in vertical profile of the weathering crust (from bottom to top): $\mathrm{D}_{1}$ (zine of breakdown, oxidizing and initial decomposition of primary aluminosilicatehydromicaceous zone) $\rightarrow D_{2}$ (allite - kaolinite - gothite zone) $\rightarrow G_{2}$ (allite zone - total removal of $\mathrm{Si}$, accumulation of $\mathrm{Fe}, \mathrm{Cu}$ - kaolinite - gothite zone) $\rightarrow \mathrm{G}_{3}$ (iron clay - gothite zone (Cuirasse)) [6].

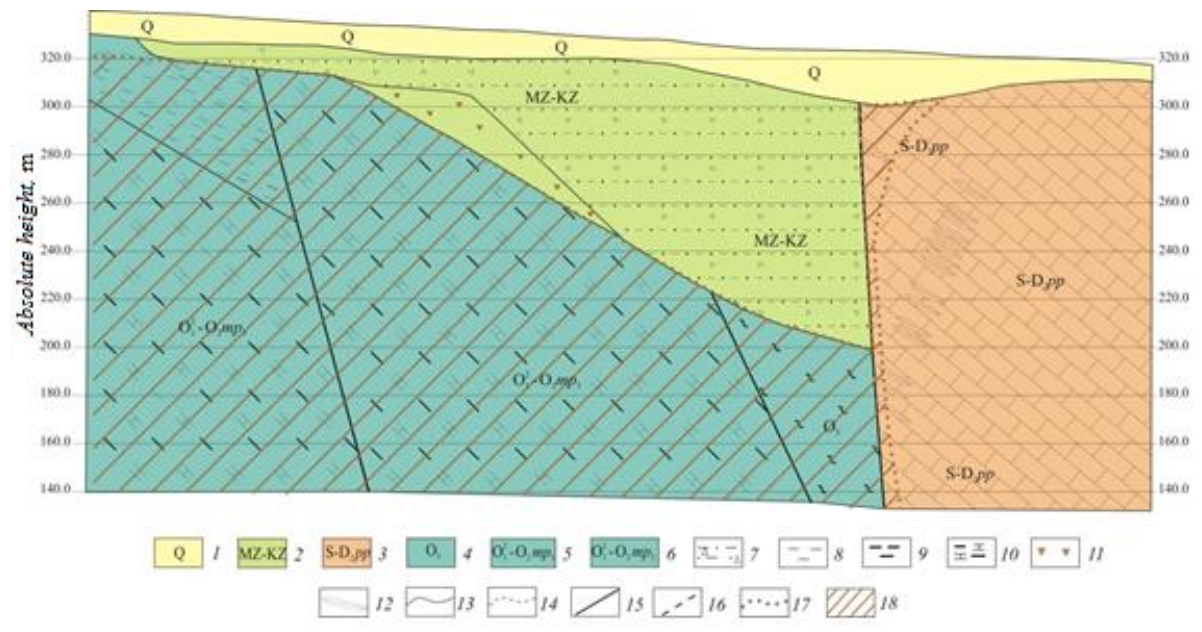

Fig. 2. Geological profile of the Sofronovskoye deposit

Age and petrographic composition of the rocks: 1 - Quaternary system: the upper modern link, not dissected deposits; 2 - Meso-Cenozoic undivided, loose deposits, performing erosion-karst depressions: phosphorites, sands, sandy loam, loam, ocher; 3 - Silurian system: the middle section of the Devonian Formation. Paypudynsky suite, marbled limestones; 4 - Horde system: upper section. Productive retinue. Phosphorites, phosphate-containing sericite-quartz schists, marbled limestones; 5 Ordovix system. Malopaypudynsky suite, upper stratum, carbonate-quartz carbonate phosphatebearing schists, sandstone, limestone sandstones, siltstones, siltstones; 6 - Ordovician system. Malopaypudynskaya suite, medium thickness, sandstones, siltstones, siltstones, mudstones; 7 unsorted loose deposits of erosion-karst depressions, sandy loam, loam with clastic material up to $30 \%$ (crushed stone, wood, pebbles, gravel, less often blocks, boulders); 8 - shale, siltstone sericite-quartz, chlorite-sericite-quartz; 9 - carbonic schists sericite-quartz; 10 - carbonate-quartz carbonate schists; 11 - phosphate rock weathering; 12 - karst cavity (off-scale sign). 13-17 - other boundaries of stratigraphic and intrusive subdivisions of different ages, lithological differences of geological bodies 
within stratigraphic subdivisions: 13 - identified, 14 - alleged, 15 - discontinuous violations, $16-$ boundaries of the formation of the weathering crust, 17 - boundary of the development of the weathering crust, 18 - weathering crust.

In accordance with the engineering-geological clasisfication, the weathering crusts are divided in two zones: IV - clay zone, and V - secondary cementing zone.

The clay zone $(I V)$ is divided in two sub-zones - clay and lateritic ones. The clay subzone is formed by clays and sand clays (phosphate-free, phosphate-containing and phosphatebearing). Chlorite - montmorillonite composition group is prevailing among the clay minerals.

The lateritic sub-zone is formed by clayed sands or very fine-grained sands. The rock composition is phosphate-clay, the main minerals therein are: hydrous micas, hydrochlorite, montmorillonite, vermiculite.

The secondary cementing zone (structural bauxite and Cuirasse sub-zones) is represented by phosphorites (kaolin type, silica-clay type) and brecciform, brown clay iron ores, cavernous phosphorites. Kaolin type phosphorites are result of intensive desalinization and breakdown, brecciform phosphorites are products of hypergene metasomatism, brown clay iron ores are hydrolysis products. Based on their physical and mechanical properties, they belong to a group low and moderate strength rocks, with $\rho=2.91-2.26 \mathrm{~g} / \mathrm{cm}^{3} ; n=3-4 \%$; $\rho_{s}=3.04-3.14 \mathrm{~g} / \mathrm{cm}^{3}$.

Permafrost conditions. Lateral extension of perennially frozen rocks is nonuniform both in plane, and in profile. Even though most of the rock mass is in frozen condition, some areas are noted where perennially frozen rocks are either not present, forming subgelisol, or the top of perennially frozen rocks is embedded up to 5-75 $\mathrm{m}$ depth; in addition, linear subgelisol zones, wherein the temperatures are above zero to the depths up to 200 , are observed.

Subgelisol zones are assigned to tectonic zone and flooded. Differentiation in structure of frozen rock masses is noted in vertical structure section, so the Central and Northern areas of the deposit have massive structure of the mass of perennially frozen rocks, however permafrost rocks are observed in sections (Figure 3). The depth of perennially frozen rocks is $100-150 \mathrm{~m}$. The Southern part of the deposit also features massive extension of perennially frozen rocks, and its depth goes to $200-300 \mathrm{~m}$. The rock temperatures vary from $0^{\circ} \mathrm{C}$ to $(-1)^{\circ} \mathrm{C}$. 

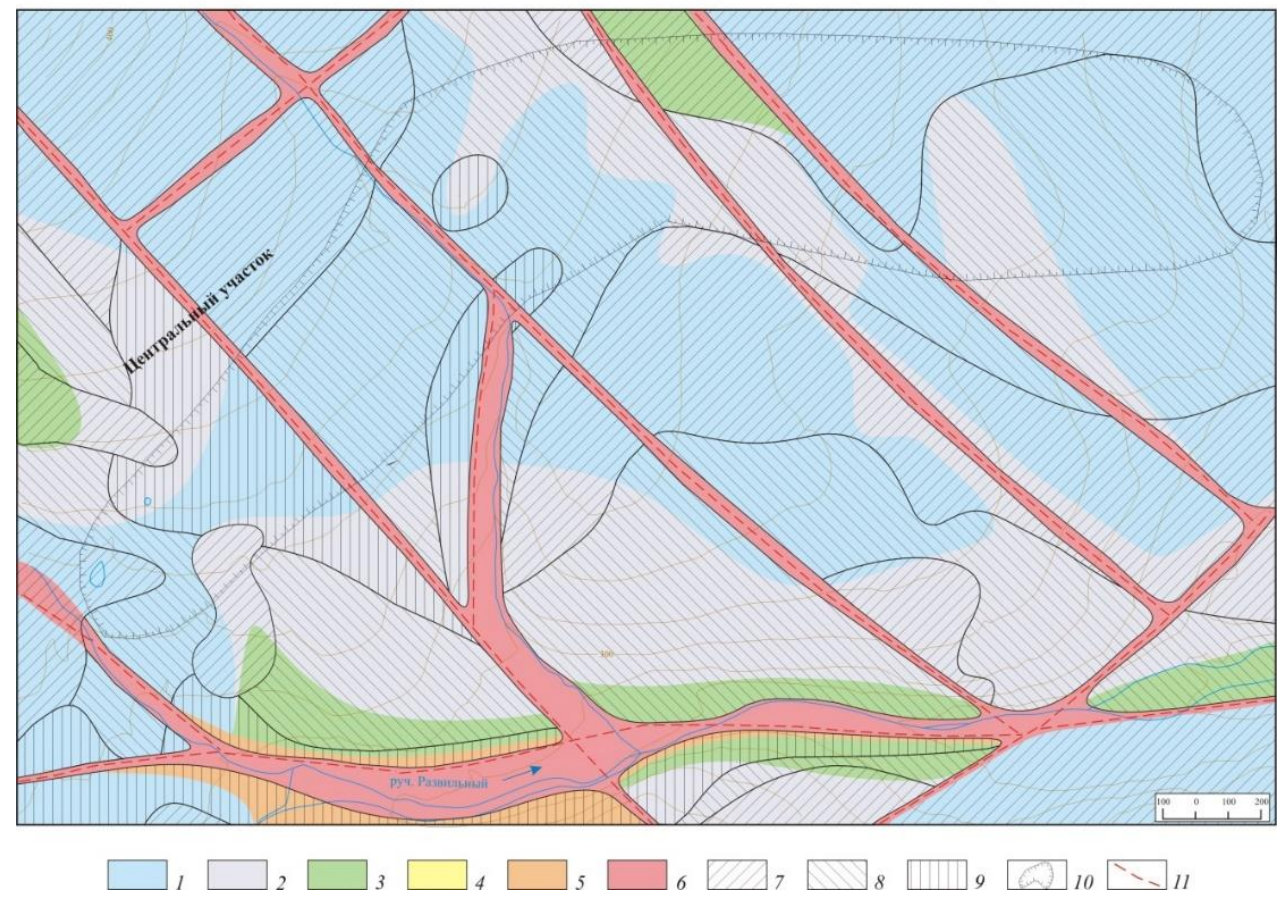

Fig. 3. Fragment of permafrost distribution map of Sofronovskoye deposit

Frozen rocks with a roof: 1 - from the surface; 2 - at a depth of 5-25 $\mathrm{m} ; 3$ - at a depth of 25-50 $\mathrm{m}$; 4 at a depth of 50-75 m; 5- at a depth of 75-100 m; $6-$ at a depth of more than $100 \mathrm{~m}$. The opened thickness of the permafrost; 7 - up to $50 \mathrm{~m} ; 8-50-100 \mathrm{~m} ; 9$ - more than $100 \mathrm{~m} ; 10$ - contour of the designed quarry; 11 - weakly water-bearing, locally-waterproof subcryogenic zone of tectonic disturbances.

It should be noticed while analyzing the structure and properties of deposit that both lower and upper strata rocks are frozen, however some areas of thawed rocks are also observed.

The frozen rocks of the upper strata are represented by sabulous-clayey/argillaceous sand, argillaceous sand, sand and rubbly rocks populated with alternately located ice inclusions. The ice contained in the rocks forms the rock texture: this is either ice cement or segregated ice. Combination of relatively non-homogenous lithological composition and different degree of rock wetness by the permafrost start point resulted in formation of cryogenic textures: massive, schlieren textures, netted textures, bread-crust textures. The massive textures are common for sand and sabulous-clayey formations, schlieren and netted textures for argillaceous sand ones, bread-crust texture for karst aggregate. Segregated ice in rocks of the deposit has different forms and sizes from the tiniest crystals and veins to pockets and veins of greater volumes. The sand and sandy-loam varieties are characterized by densities of 1.81-1.99 g/ $\mathrm{cm}^{3}$, total volume content of ice 0.34-0.49 unit fractions, thawing coefficient $0.008-0.013 \mathrm{MPa}$. Sandy-loam varieties are characterized by density $1.5 \mathrm{~g} / \mathrm{cm}^{3}$, and total volume content of ice 0.51 unit fractions.

Solid rocks (quartz sandstones, silty sandstones, calcareous sandstones) have a dry strength of 57.9-85.2 MPa, hardness coefficient 5-7, these rocks can't be macerated.

The nature and degree of karsting of the rocks. The deposit is characterized by the following surface and subsurface karst forms: cenote/sinkholes, karst-underwashing, and mixed type forms are observed among the surface ones. Swallow holes are observed in the bottom of sinkholes. The sinkholes distribution is non-homogenous, the density of karst 
forms amounts to $5-10 \mathrm{pcs} / \mathrm{km}^{2}$, their concentration is observed in tectonic disturbance zones. The subsurface karst forms feature carstified fissures, pockets, caverns. Analysis of total karst ratio $(\mathrm{Kz})$ changing with the depth showed that it falls within $16-20 \%$ at depths up to $140 \mathrm{~m}$, within $10-20 \%$ down to $240 \mathrm{~m}$, and then decreases to $1 \%$. The change of total karst ratio in plan also showed its differentiation, and it was the basis for identification of highly carstified rock areas (Southern area of the deposit), moderately carstified rock areas (Northern area) and micro- carstified rock areas (Central area) (Table 2).

Table 2. The degree of karsting of the rock massif of the Sofronovskoye deposit

\begin{tabular}{|c|c|c|c|c|c|}
\hline Plot & $\begin{array}{l}\text { Depth, } \\
\text { m }\end{array}$ & $\begin{array}{c}\text { The total karst } \\
\text { ratio, } \%\end{array}$ & $\begin{array}{c}\text { Number of } \\
\text { karst cavities, } \\
\text { pcs }\end{array}$ & $\begin{array}{c}\text { Dimensions } \\
\text { of karst } \\
\text { cavities, } m\end{array}$ & Karst category \\
\hline \multirow[t]{2}{*}{ North } & $0-90$ & $20-24$ & \multirow{2}{*}{98} & \multirow{2}{*}{$1.5-10.0$} & \multirow{2}{*}{$\begin{array}{l}\text { Medium- } \\
\text { karst }\end{array}$} \\
\hline & $90-180$ & 1 & & & \\
\hline \multirow[t]{3}{*}{ Central } & $0-140$ & 18 & \multirow{3}{*}{266} & \multirow{3}{*}{$0.5-27.0$} & \multirow{3}{*}{$\begin{array}{l}\text { Weak- } \\
\text { karst }\end{array}$} \\
\hline & $\begin{array}{c}140- \\
180\end{array}$ & 26 & & & \\
\hline & $\begin{array}{c}250- \\
260\end{array}$ & 1 & & & \\
\hline \multirow[t]{3}{*}{ South } & $0-50$ & $12-24$ & \multirow{3}{*}{105} & \multirow{3}{*}{$0.5-25.0$} & \multirow{3}{*}{$\begin{array}{l}\text { Highly- } \\
\text { carded }\end{array}$} \\
\hline & $50-240$ & 26 & & & \\
\hline & $>240$ & 9 & & & \\
\hline
\end{tabular}

Therefore, it should be noticed that geological profile of the deposit is very complex, and the human impact will drive it to further changes. The spatial patterns identified at the stage of survey suggest that the northern and western edges of the open-pit mine formed by icy weathering crusts will be exposed to deep thawing at their opening, which will cause damage of the rock structure and possible development of soil slips. The eastern and southern edges formed by weathering crusts in the upper parts will also be exposed to deformations, and the bottom part formed by carstified rocks would encourage flooding of the massif and increased water inflows; soil slips can also progress with opening of the karst filler aggregate.

\section{References}

1. K. Rollins, D. Zekkos (Eds.), Geotechnical Engineering State of the Art and Practice. Keynote Lectures from GeoCongress, ASCE, 832 (2012)

2. S. Hencher, Practical Engineering Geology, 450 (Spon Press, 2012)

3. V.D. Babushkin, D.I. Peresunko, Analysis of hydrogeological and engineeringgeological conditions at exploration and development of solid mineral deposits, 408 (Moscow, Nedra Press, 1969)

4. G.K. Bondarik, L.A. Jarg, Soil Surveying, 418 (Moscow: KDU (University Press), 2014)

5. G.S. Zolotarev, Contemporary problems of engineering-geological weathering processes and crusts. Issues of engineering-geological studies of weathering processes and crusts, 4-25 (Moscow: Moscow University Press, 1971)

6. V.I. Kuzkin, L.A. Jarg, Guideline for survey of engineering-geological conditions of ore deposits at exploration, 153 (Moscow, Nedra Press, 2001)

7. L. A. Jarg, Engineering-geological study of weathering process, 235 (Moscow, Nedra Press, 1987)

8. I. Abaturova et al., Gornyi Zhurnal, 9, 22-27 (2015) doi: 10.17580/gzh.2015.09.04

9. I. Abaturova et al., EAGE, 2018(1), 1-6 (2018) doi: 10.3997/2214-4609.201802460

10. P. Gattinoni, E. M. Pizzarotti, L. Scesi, Engineering Geology for Underground Works, 312 (Springer, 2014) 